\title{
Knowledge of the nursing team about the newborn's pain
}

\section{Conhecimento da equipe de enfermagem sobre a dor do recém-nascido}

\author{
Nayara Freitas Azevedoํ, Thiago Dias², Maria Paula Custódio Silva², Mayline Verônica Rocha Sampaio², Jesislei Bonolo
} do Amaral $^{2}$, Divanice Contim²

DOI 10.5935/2595-0118.20190061

\section{ABSTRACT}

BACKGROUND AND OBJECTIVES: To describe the knowledge of the nursing team about the evaluation and treatment of pain in newborns hospitalized at the Neonatal Intermediate Care Unit of a university hospital in the state of Minas Gerais, due to the relevance of the issue regarding the quality of the neonatal care.

METHODS: A descriptive and exploratory qualitative research with 13 professionals from a Neonatal Intermediate Care Unit. The data were collected through a semi-structured interview, and the data analysis was guided by the Content Thematic Analysis from January to June 2018.

RESULTS: Four categories were elaborated: pain identification; methods for assessing pain; interventions of the nursing team to relieve pain, and nursing learnings in pain management.

CONCLUSION: The knowledge of this team is based on the individual experience, showing the need for changes in the educational structures to reach better results and nursing practices based on scientific methods for quality assistance.

Keywords: Infant, Knowledge, Neonatal nursing, Newborn, Nursing team, Pain.
Nayara Freitas Azevedo - (Dhttps://orcid.org/0000-0001-7748-4777;

Thiago Dias - Dhttps://orcid.org/0000-0003-4343-2287;

Maria Paula Custódio Silva - (Dhttps://orcid.org/0000-0001-8694-1589;

Mayline Verônica Rocha Sampaio - (Dhttps://orcid.org/0000-0002-0522-1174;

Jesislei Bonolo do Amaral - (Dhttps://orcid.org/0000-0002-0591-7972;

Divanice Contim - Dhttps://orcid.org/0000-0001-5213-1465.

1. Universidade de São Paulo, Departamento de Enfermagem, São Paulo, SP, Brasil.

2. Universidade Federal do Triângulo Mineiro, Departamento de Enfermagem, Uberaba, MG, Brasil.

Submitted on June 27, 2019.

Accepted for publication on October 08, 2019.

Conflict of interests: none - Sponsoring sources: none.

Correspondence to:

Divanice Contim

Universidade Federal do Triângulo Mineiro

Rua Frei Paulino, 30

38025-180 Uberaba, MG, Brasil.

E-mail: d.contim@uol.com.br

(c) Sociedade Brasileira para o Estudo da Dor

\section{RESUMO}

JUSTIFICATIVA E OBJETIVOS: Descrever o conhecimento da equipe de enfermagem sobre a avaliação e o tratamento da dor em recém-nascidos internados na Unidade de Cuidado Intermediário Neonatal de um hospital universitário do estado de Minas Gerais, pela relevância da temática no que se refere à qualidade da assistência neonatal.

MÉTODOS: Pesquisa de abordagem qualitativa do tipo descritiva e exploratória, com 13 profissionais de uma Unidade de Cuidados Intermediários Neonatal. Os dados foram coletados por meio de entrevista semiestruturada e a análise de dados foi orientada pela Análise Temática de Conteúdo nos meses de janeiro a junho de 2018.

RESULTADOS: Foram elaboradas quatro categorias: identificaçâo da dor; métodos para a avaliaçấo da dor; intervençôes da equipe de enfermagem para o alívio da dor; aprendizado da enfermagem no manuseio da dor.

CONCLUSÁO: O conhecimento dessa equipe está baseado na experiência individual e registram necessidades de mudanças nas estruturas formativas para o alcance de melhores resultados e práticas de enfermagem, fundamentadas em métodos científicos para uma assistência de qualidade.

Descritores: Conhecimento, Dor, Equipe de enfermagem, Enfermagem neonatal, Recém-nascido.

\section{INTRODUCTION}

The International Association for the Study of Pain (IASP) ${ }^{1}$ defines pain as an unpleasant sensory and emotional experience associated with a tissue injury, real or not. Its assessment requires skill, training, and humanized treatment, especially of nursing staff professionals, as they stay longer in contact with the newborn $(\mathrm{NB})^{1,2}$.

Exposure to severe or prolonged pain may increase neonatal morbidity. Infants who experienced pain during the neonatal period respond differently to subsequent painful events. Given these consequences, studies started to be conducted to improve treatment strategies to prevent and treat NB pain and discomfort ${ }^{1-4}$.

The NB expresses pain through crying, facial mimics, body movement, sleep disturbance, and physiological changes. This demonstrates that professionals need to recognize these signals, assess them and treat them correctly. In this process, the use of scales that take these behaviors into consideration may prove to be a viable resource ${ }^{3}$.

Pain is recognized as a vital variable to be assessed in the clinical practice of NB treatment, and its non-recognition 
is a matter of concern. Scientific productions on the theme demonstrate the importance of knowledge of nursing professionals, in order to avoid the occurrence of iatrogenesis, since NB when hospitalized in neonatal units, are exposed to painful sensation due to the disease itself, which can be potentiated due to physiological stress and invasive procedures, often without pain relief interventions $s^{5-7}$.

From this perspective, the assessment and control of pain in NB constitute a significant challenge for health professionals, including those of the nursing staff, who live with the particularities of the neonatal period, seeking ways to prevent and/or mitigate $i^{4}$, respecting the right of the NB not to feel pain ${ }^{8}$. The production of the knowledge developed here may help nurses to identify gaps in the nursing staff's knowledge about neonatal pain, contributing significantly to the improvement of the quality of care provided to this population group.

This study aimed to describe the knowledge of the nursing staff on pain assessment and treatment in NB admitted to a Neonatal Intermediate Care Unit (NICU).

\section{METHODS}

A descriptive exploratory study with a qualitative approach ${ }^{9}$ was conducted in a NICU of a teaching hospital located in the Southern Triangle of the state of Minas Gerais. During the study, the nursing staff was composed of 24 professionals, being eight certified nurses, and 16 nurse practitioners.

The inclusion criterion to select the participants was professionals who have been working for more than a year in the study unit, understanding that this environment requires time to know the constituent elements of the work process of the unit. Professionals in sick leave and vacation were excluded.

The entire nursing staff was invited to participate in the study after the presentation of the objectives. After verbal acceptance, date, time, and place were scheduled, according to the professional's preference for the interviews.

The information was collected from January to June 2018, through semi-structured interviews in two stages. The first stage contained sociodemographic data, and the second was guided by the following open questions: do you believe the NB feels pain? What situations cause pain in the NB? What methods do you use to assess the NB pain? Do you use scales to identify the NB pain? Have they helped identify pain? What are the signs and symptoms that lead you to interpret that the NB is in pain? What are the interventions (pharmacological and non-pharmacological) that nursing uses to control NB pain?

Upon consent, data were collected individually and privately, and the interviews were recorded with the prior consent of the participants, later transcribed, and with an average duration of 15 minutes. In order to maintain anonymity, they were identified with the letter $\mathrm{N}$ of "nurse" and NP of "nurse practitioner" and subsequent numbers, according to the order in which data collection was performed, for example, N1, N2, NP1, NP2 ... The number of participants was defined by the data saturation criterion that allows a more detailed analysis of the relationships established in the research environment and the understanding of meanings and systems ${ }^{10}$. Data analysis was guided by Thematic Content Analysis, respecting its stages ${ }^{11}$. In the pre-analysis, performed through the fluctuating reading of the printed interviews, the points of interest are highlighted, followed by the exploration of the material in a thorough and exhaustive way, performing the classification and coding of the interviews, with apprehension of the nuclei of meaning, which were grouped, generating the empirical thematic categories responsible for the theme specification. Finally, the interpretation of the obtained results was performed, which were discussed and analyzed with the literature on the theme, to answer the objective proposed in this research.

The development of the study complied with the national and international standards of Ethics in Research involving human beings, complying with Resolution MS/CNS 466/2012, and signing the Free and Informed Consent Form (FICT), in two copies, after approval by the UFTM Research Ethics Committee according to CAAE: 63030416.1.0000.5154 and Opinion No. 1.974.515.

\section{RESULTS}

Thirteen professionals of the nursing staff were interviewed, all female, four nurses and nine nurse practitioners, aged between 28 and 62 years, with an average of 45 years. The professional experience ranged from five to 40 years, with an average of 17.8 years. Of the participants, one nurse is specialized in neonatology. After analyzing the interview transcripts, the speech categorization was performed, emerging four categories:

\section{Identification of the newborn pain}

All professionals reported that the NB experiences painful experience in situations of manipulation for procedures such as venipuncture, positioning, intubation, blood glucose test, and heel prick test. Pain has been reported to be associated with the clinical picture, such as diagnosis of hydrocephalus, fever, postoperative situations, thermal variations, and the delivery itself, as follows:

Manipulation... procedures, especially those that pierce the skin as venipuncture ... blood collection for tests, heel prick test, various invasive procedures such as probing, catheterization, intubation (N4).

Discomfort, any kind of discomfort, whether high or low temperature... noise... the absence of the mother (NP9).

It depends on the picture... that little baby there has hydrocephalus... feels a lot of pain, we believe it is the pressure on her head because she has a lot of fluid (NP5).

\section{Methods for assessing newborn pain}

According to the reports, pain is assessed using signs and symptoms presented by the NB, such as crying, facial and body expressions, the degree of agitation, and assessment of the vital signs, such as the presence of tachycardia. 
The irritability, the face itself..., the restlessness, the kind of desperate crying, is a cry that does not calm down (N1).

Every time he starts debating his arms and his little hands, his little legs, we know he's in pain (N3).

It's a different cry... he gets angry, gives a tachycardia (NP9).

In the speech analysis, it was noticed that in the service, validated scales for the measurement of NB pain are not yet used. Some reports point to a graphic scale of pain in the vital signs sheet, but not intended for the target audience.

As we do not have an instrument, we look a lot at the intensity of crying and pain faces (N2).

We are not currently using any pain scale, any scientific method. So today, we assess by perception, right (N4).

Look, we have those little scales with faces, but I don't take much into account ... not that, because actually... I think that you can't talk about 1 to 10 what is the baby's pain (NP7).

In the speeches, it was possible to identify that the team knows the physiological changes that the NB presents when feeling pain, but the use of a measurement protocol was not reported. One of the nurses interviewed cited the NB assessment scales used in the institution she had previously worked. In the other institution where I worked, we worked with child pain protocol ... non-pharmacological measures for child pain relief... and we also worked with the NIPS scale and the CHEOPS scale, which is the assessment of the child's pain, but it has not yet been institutionalized here (N4).

\section{Nursing staff interventions for newborn pain relief}

Among the interventions used by the nursing staff are pharmacological and non-pharmacological. It was observed in the reports that the most prescribed drugs by doctors are analgesics and anti-inflammatory drugs. They mentioned dipyrone, acetaminophen, and simethicone as the most used. Sucrose was pointed and associated with suction, despite the routine use, there were differences to which type of method it belongs.

Pharmacological only when there is a medical prescription, right. So, it would be the painkillers that doctors prescribe, acetaminophen, dipyrone, or simethicone (N2).

There is very little time here in the institution we are using sucrose, right. Then the little finger with the sucrose glove (N3).

The medications that sometimes the doctor gives are dipyrone, tilenol, dimethicone, depending on the case. And according to the case of the child, sometimes even a stronger medication (NP3).

Among the non-pharmacological interventions, the correct positioning of the NB, cuddling, swaddling, and non-nutritive sucking were observed in the speeches.

So, it's the same thing, the swaddling, sometimes that baby is in pain, is very agitated, you swaddle, non-nutritive sucking, put the gloved finger a few drops of glucose (N1).

The comfort that is to swaddle the newborn makes it more comfortable, minimal handling and non-nutritive suction (N2).

The first method we use is to position it correctly, to cuddle with our own hands, and if it does not improve, what are we doing? Give a pacifier sometimes, here we make a glove pacifier (NP3).

\section{Nursing learning in newborn pain management}

In the interviews, the participants pointed out that $\mathrm{NB}$ pain management is not a curricular component during vocational training. The speeches show that the handling is performed due to the professional experience gained over time. Insecurity and even despair in dealing with the NB pain were observed due to this previous unfamiliarity.

The other speeches revolve around the experience as mothers and the years of working with NB and children.

It's with no scales, right? (laughs), as we learn. It seems that the more experience you get in practice, it seems that you are be able to assimilate better. At first, it is a bit despairing! Everyone is crying! Everyone is in pain! (N1).

Well, I'm a mother (laughs), after I started working here, it was with the experience from the other professionals (N2).

That's 25 years of experience; we have to learn from living together, with daily life, with work (NP7).

There was also a report in which a professional believes that there is no way to avoid pain. Pain, for her, is treated after interventions and procedures performed with NB:

No, I didn't learn it. Actually, we can't handle the pain. What we do is, after the child has felt all the pain that the procedure brings to him/her, is to cherish him/her (E3).

\section{DISCUSSION}

The painful experience was identified by the nursing staff professionals in observing behavioral characteristics such as crying, facial mimic, motor activity in invasive procedures, and the clinical picture of the NB. They considered the need to systematize pain assessment; however, in the unit studied, no strategies are used in this regard.

Pain may be associated with impaired neurological, physical, and behavioral development. A multimodal approach to NB pain management improves prognosis, reduces suffering and stress $^{12,13}$. The IASP ${ }^{1}$ indicates as key elements in pain management the quality of care provided, the presence of institutional protocols, continued education for health teams, and standards of registration ${ }^{14}$.

The assessment and treatment of pain in NB face several barriers, such as its inability to verbalize and the absence of standards of care, which imply empirical and distinct treatment by the professionals ${ }^{15}$. It is believed that scientific knowledge and clinical practice management are the hurdles to assess and measure pain in the NB, indicating the need for training of multidisciplinary teams and the increase of routines/protocols to assess and control pain in this population ${ }^{12-16}$.

It is not recommended to assess pain in this life cycle with graphical and numerical scales because it does not include adequate indicators. This study identified the non-systematization of the use of specific scales for pain assessment in the NB. The existence of gaps regarding the knowledge of nursing professionals about pain management and assessment is evidenced ${ }^{14-17}$. Despite the several scales, they are not applied or used correctly ${ }^{14}$. A study conducted in a neonatal unit in the Midwest Region observed that most professionals report- 
ed knowing some pain assessment scale, and the most known and applied was the Neonatal Infant Pain Scale (NIPS) ${ }^{18}$.

Prolonged exposures to painful stimuli are known to have long-term consequences on the NB's brain response, reinforcing the need to assess and treat pain adequately, and the promptness in meeting the NB needs ${ }^{16}$. It is believed that to reduce the NB pain, we should limit the number of invasive procedures, assess the safety and efficacy of drugs, and combine them with non-pharmacological therapies ${ }^{14}$. The drugs mentioned by the participants were dipyrone, paracetamol, and simethicone, the most cited in the literature ${ }^{3,14,19}$. It was observed that its use is the first choice when not using an assessment instrument ${ }^{3,14}$.

The non-pharmacological methods indicated were non-nutritive sucking, the use of sucrose, the positioning of the NB, swaddling, the cuddling and minimum manipulation. The kangaroo-mother care method, the little package, and cuddling, much used in pain relief ${ }^{20}$, are considered soft technologies to care for the babies. Other measures such as NB massage and bath therapy may be employed to promote relaxation, improve sleep quality and minimize the effects of painful stimuli, and can be applied by the nursing staff. Many nurses are unaware of such techniques, so these themes should be included in the education of nurses in neonatal units ${ }^{20}$. The stimulation of the mother's voice before and during painful procedures, such as heel-stick puncture, has a positive effect on the vital signs of $\mathrm{NB}$, being a practice to be considered for this type of procedure ${ }^{21}$.

Regarding the divergence in considering sucrose a pharmacological method, the literature refers to it as non-pharmacological interventions $s^{3,17,18,22}$. Sucrose or $25 \%$ glucose administration is recommended two to three minutes before minor painful procedures, such as a heel-stick puncture or venous puncture, in the anterior portion of the tongue, with a limit of 10 doses per day ${ }^{18}$. It can be used in combination with non-nutritive suction, which increases the release of endogenous endorphins. Providing comfort to the NB through the other methods mentioned helps to reduce pain because it facilitates the organization and self-regulation ${ }^{17}$. The lack of registration of these methods in the patient's record was an obstacle found in the literature ${ }^{15-17}$.

Among the difficulties reported by the participants, the lack of institutional standardization based on physiological and behavioral changes stood out. Similar research pointed to crying as the most cited manifestation by doctors and nursing staff, followed by facial mimic and limb movement; in the face it is possible to assess the protruding forehead, narrowed eyes, and tight mouth as pain indicators ${ }^{16}$. Before performing painful procedures, attention should be paid to noise and light, as they interfere with the comfort and organization of the NB and may potentiate the painful stimulus ${ }^{23}$.

Research on this theme points to the need for changes at all levels of education, based on solid foundations that legitimize the knowledge transfer to implement neonatal pain assessment and management ${ }^{2,14-18}$. Therefore, it is necessary to investigate the personal, structural, and organizational barriers that pre- vent or hinder professionals from applying the acquired knowledge. Teaching pain management to health professionals at all levels of education has been identified as an important measure to change the ineffective practices performed. However, most educational programs, especially for undergraduates, include minimum or no content on the theme $\mathrm{e}^{19,20,22}$. The literature lacks studies on pain during academic education. Among the findings, a research conducted with medical students regarding the recognition of pain in NB is highlighted ${ }^{22}$.

IASP ${ }^{1}$ establishes curriculum guidelines for teaching acute and chronic pain, in undergraduate and postgraduate courses, with an emphasis on interdisciplinarity. This recommendation is important in directing the curriculum matrix of nursing courses. However, it is observed that learning occurs in daily practice, depending on the concepts and prejudices in daily life ${ }^{1,17}$.

It is understood that the study results contribute to the advancement of scientific knowledge in neonatal nursing and the planning of local actions. It is relevant and necessary to review the nursing undergraduate curricula based on IASP $^{1}$ recommendations and guidelines to apply appropriate interventions aimed at the quality of care.

\section{CONCLUSION}

The study made it possible to identify that the staff knowledge is based on the personal experiences acquired with the time of service at the NICU. The reports show the absence of institutional protocols for pain assessment with scales and identify the need to incorporate pain assessment into the curriculum plans of health professionals to improve the quality of care provided.

\section{REFERENCES}

1. International Association for the Study of Pain. Subcommittee on Taxonomy. Pain terms: a list with definitions and notes on usage pain. [Internet]. 2018 [acesso em: 07 fev. 2019]. Disponível em: https://www.iasppain.org/Education/Content.aspx?ItemNumber $=1698$.

2. Anand KJS. Defining pain in newborns: need for a uniform taxonomy? Acta Paediatr 2017;106(9):1438-44.

3. Costa T, Rossato LM, Bueno M, Secco IL, Sposito NP, Harrison D, et al. Nurses's knowledge and practices regarding pain management in newborns. Rev Esc Enferm USP. 2017;(51):e03210. English, Portuguese.

4. Alves FB, Fialho FA, Dias IM, Amorim TM, Salvador M. Dor neonatal: a percepção da equipe de enfermagem na unidade de terapia intensiva neonatal. Rev Cuid. 2013;4(1):510-5.

5. Santos LM, Pereira MP, dos Santos LF, de Santana RC. [Pain assessment in the premature newborn in Intensive Care Unit]. Rev Bras Enferm. 2012;65(1):27-33. Portuguese.

6. Gaíva MA, Blanco e Silva F, Azevedo FM, Rubira EA. Procedimentos dolorosos em recém-nascidos prematuros em unidade terapia intensiva neonatal. Arq Ciênc Saúde. 2014;21(1):48-54

7. Cruz MD, Fernandes AM, Oliveira CR. [Epidemiology of painful procedures performed in neonates: a systematic review of observational studies]. Eur J Pain. 2016;20(4):489-98.

8. Resoluçáo no 41 do Conselho Nacional de Saúde, de 13 de outubro de 1995 (BR) Direitos da Criança e do Adolescente hospitalizados. Diário Oficial da União. 17 out 1995 [acesso em: 07 fev 2019]. Disponível em: http://www.mpdft.mp.br/portal/pdf/ unidades/promotorias/pdij/Legislacao\%20e\%20Jurisprudencia/Res_41_95_Conanda.pdf.

9. Polit DF, Beck CT, Hungler BP. Fundamentos de Pesquisa em enfermagem: métodos, avaliação e utilizaçấo. 7a ed. Porto Alegre: Artmed Editora; 2011

10. Hennink MM, Kaiser BN, Marconi VC. Code saturation versus meaning saturation: how many interviews are enough? Qual Health Res. 2017;27(4):591-608.

11. Bardin L. Análise de conteúdo. 4a ed. Lisboa: Ediçóes 70; 2011. 280p. 
12. Oliveira RM, Silva AVS, Silva LMS, Silva APAD, Chaves EMC, Bezerra SC. Implementação de medidas para o alívio da dor em neonatos pela equipe de enfermagem. Esc Anna Nery. 2011;15(2): 277-83.

13. Hatfield LA, Murphy N, Karp K, Polomano RC. A systematic review of behavioral and environmental interventions for procedural pain management in preterm infants. J Pediatr Nurs. 2019;44:22-30.

14. Capellini VK, Daré MF, Castral TC, Cristoffel MM, Leite AM, Scochi CG. Conhecimento e atitudes de profissionais de saúde sobre avaliação e manejo da dor neonatal. Rev Eletr Enferm. 2014;16(2):361-9.

15. Marcondes M, Costa AMD, Chagas EK, Coelho JBA. Conhecimento da equipe de enfermagem sobre a dor no recém-nascido prematuro. Rev Enferm UFPE. 2017;11(9):3354-9.

16. Prevention and management of pain in the neonate: an update. Pediatrics. 2006;118(5):2231-41.

17. Christoffel MM, Castral TC, Daré MF, Montanholi LL, Scochi CG. Knowledge of healthcare professionals on the evaluation and treatment of neonatal pain. Rev Bras Enferm. 2016;69(3):552-8. English, Portuguese.
18. Oliveira IM, Castral TC, Cavalcante MM, Carvalho JC, Daré MF, Salge AK. Conhecimento e atitude dos profissionais de enfermagem sobre avaliaçâo e tratamento da dor neonatal. Rev Eletr Enferm. 2016;(18):e1160.

19. Watt-Watson J, Hunter J, Pennefather P, Librach L, Raman-Wilms L, Schreiber M, et al. An integrated undergraduate pain curriculum, based on IASP curricula, for six health science faculties. Pain. 2004;110(1-2):140-8.

20. Nóbrega AS, Cantalice AS, Cerqueira AC, Santos NC, Bezerra NA, Chaves TR. Tecnologias de enfermagem no manejo da dor em recém-nascidos na unidade de terapia intensiva neonatal. Enferm Foco (Brasília). 2018;9(2):66-72.

21. Chen YS, Tan YJ, Zhou LS. [Clinical effect of maternal voice stimulation in alleviating procedures pain in hospitalized neonates]. Zhongguo Dang Dai Er Ke Za Zhi. 2019;21(1):58-63. Chinese.

22. Silva AP, Balda RC, Guinsburg R. Reconhecimento da dor no recém-nascido por alunos de medicina, residentes de Pediatria e Neonatologia. Rev Dor. 2012;13(1):35-44.

23. Maciel HIA, Costa MF, Costa ACL, Marcatto JO, Manzo BF, Bueno M. Pharmacological and nonpharmacological measures of pain management and treatment among neonates. Rev Bras Ter Intensiva. 2019;31(1): 21-6. English, Portuguese. 